\title{
High Gain Power Generation Based On Hybrid Renewable Energy for AC Load Application
}

\author{
Shaik Mohammad Irshad, G.P.Ramesh \\ Department of Electronics and Communication Engineering, \\ St. Peters Institute of Higher Education and Research, Avadi, Chennai 600054, India
}

\begin{tabular}{l} 
Article Info \\
\hline Article history: \\
Received Jul 30, 2018 \\
Revised Sep 30, 2018 \\
Accepted Oct 12, 2018 \\
\hline Keywords: \\
Modified Current fed Switched \\
Inverter (MCFSI) \\
Permanent magnet synchronous \\
motor (PMSM) \\
Photovoltaic (PV) \\
Proportional Integral (PI) \\
controller \\
Pulse Width Modulation(PWM) \\
Wind
\end{tabular}

\begin{abstract}
This study presents the distributed energy source based current fed inverter has generated high voltage with less passive elements. The hybrid renewable energy generation such as solar and wind has used. The single stage power generation based switched inverter has combined characteristics of both impedance source inverter and switched boost inverter. In conventional voltage source inverter has less boost ability and high electromagnetic noise immunity to the modified current fed inverter circuit. The single diode photovoltaic model and wind-based energy generation have fed into current fed switched inverter for improving high gain and high power factor. The maximum power point tracking such as incremental conductance algorithm has fast-tracking of solar power and generates continuous power to the inverter circuit. $12 \mathrm{~V}$ solar power and wind power is designed for dc power production, and the output of dc link capacitor is $118 \mathrm{~V}$ using current fed switched inverter. The current fed switched inverter is designed and implemented in MATLAB/Simulink environment.
\end{abstract}

Copyright $(\odot) 2018$ Institute of Advanced Engineering and Science. All rights reserved.

\section{Corresponding Author:}

Shaik Mohammad Irshad,

Department of Electrical and Communication Engineering,

St. Peter's Institute of Higher Education and Research,

Chennai, Tamilnadu, India.

Email: irshadphd123@gmail.com

\section{INTRODUCTION}

The voltage source inverter has less output voltage compared to the input voltage. The micro grid based input supply is given to the current fed switched inverter has enhanced the output voltage and reduce the voltage stress. The distribution generation has interfaced with power electronic converter and control method to increase the performance of drive system. The wind PMSG and photovoltaic energy-based power generation are utilized [1-3]. In recent days the operation of power electronic converter is rising, and current fed switched has single stage inverter circuit. The galvanic isolation based transformer has more attractive and utilizes the pulse width modulation for regulating the dc link current. The power converter based on control technique for reducing the total harmonic distortion and enhances the efficiency [4-5].

\subsection{Background}

The multilevel converter has introduced the voltage level, and current fed inverter circuit. The current source converter has the function in various applications such as high dynamic response and high power drives. The current source inverter has inherent voltage gain, short circuit prevention and increases the reliability [6]. The soft switch inverter based residential application for high voltage ratio. The zero commutation voltage based on the snubberless circuit with the clamping device. The performance of series-connected modules has either mismatch or partial shading the power is reduced. The parallel connection of PV modules has more advantageous than series connected device because it has less illumination dependent on open circuit voltage, 
power is less influenced by small variation in maximum power point tracking voltage, and the output voltage is less sensitive to load variation [7].

\subsection{Problem}

The incremental conductance method is used for better accuracy at the output and fast convergence speed in the photovoltaic system. The algorithm has reduced the division estimation and encounters the steady state power oscillation and the dynamic problem such as environmental changes. The nonlinear characteristics of PV module on temperature and irradiance level have enhanced the maximum power and required sensor [8].

The modified current fed switched inverter has obtained the characteristics of both impedance source inverter and switched boost inverter for high gain, and inherent shoot through protection has high electromagnetic noise immunity. The inverter has widely used in both photovoltaic and wind energy generation and continuous supply of power to high gain. The incremental conductance based maximum power generated from the photovoltaic supply. The sinusoidal pulse width modulation is utilized in inverter circuit fed AC load application.

\subsection{Objectives}

a) To generate high voltage using less passive elements based on distributed energy resources powered current fed switched inverter

b) To implement incremental conductance MPPT algorithm to extract continuous power from distributed energy resource

\section{METHODS}

The proposed method utilizes the microgrid based current fed switched inverter for AC load application is shown in Figure 1. The hybrid energy such as solar, wind energy generation has used as a source of proposed modified current fed switched inverter has generate high gain voltage compared to conventional inverter methodology. The harmonics is reduced and enhances the power factor correction of proposed inverter using sinusoidal pulse width modulation in inverter circuit methodology.

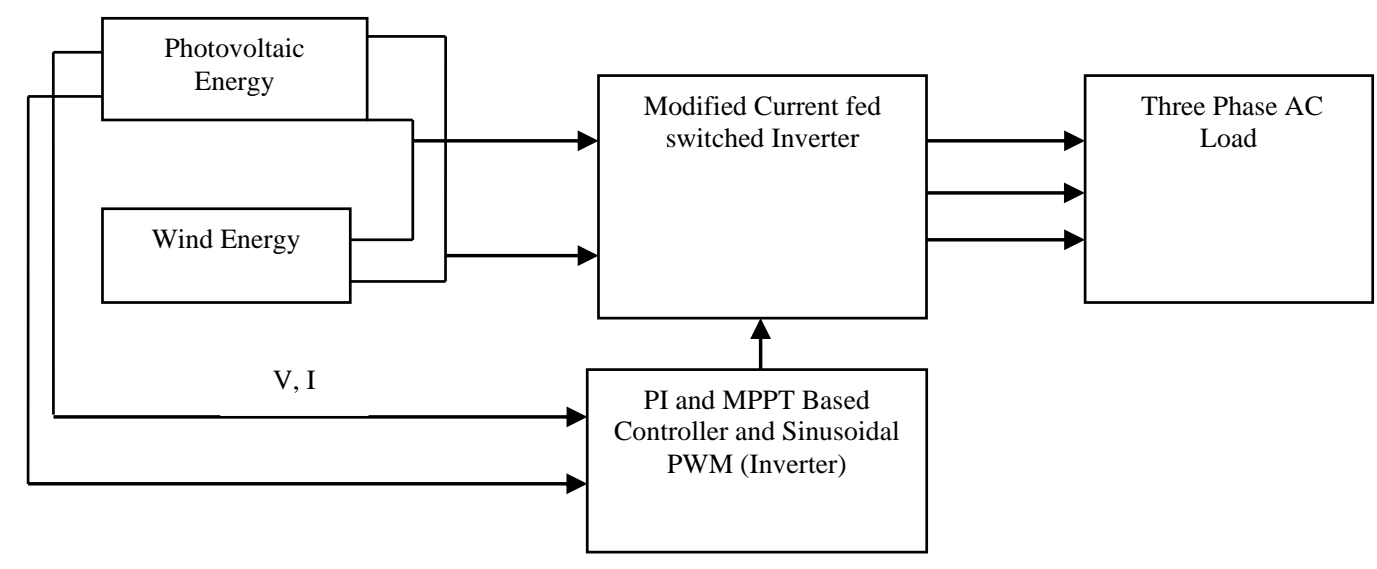

Figure 1. Block Diagram of Proposed Circuit

\subsection{Modeling Of Micro Grid}

\subsubsection{Photovoltaic Energy Generation}

The single diode photovoltaic energy generation has more reliable and connected with converter circuit for generating high voltage. The semiconductor material has used for absorption of radiation from sunlight and electron moves, thus by generating electricity. The more PV cell is connected in series to form a module. More modules are connected to form an array. The derived form of a current-voltage equation is described as by:

$$
I_{\text {solar }}=N_{P}\left\{I_{p h}-I_{0}\left\{\exp \left(\frac{q_{V_{\text {solar }}}}{n N_{S} K T}\right)\right\}\right\}
$$


Where in above Equation (1) current and Voltage of photovoltaic array is denoted by $I_{\text {solar }}$ and $V_{\text {solar }}$ respectively, short circuit current of a photovoltaic array and saturation current are denoted by $I_{p h}$ and $I_{0}$ Respectively. The circuit diagram of the photovoltaic cell is shown in Figure 2.

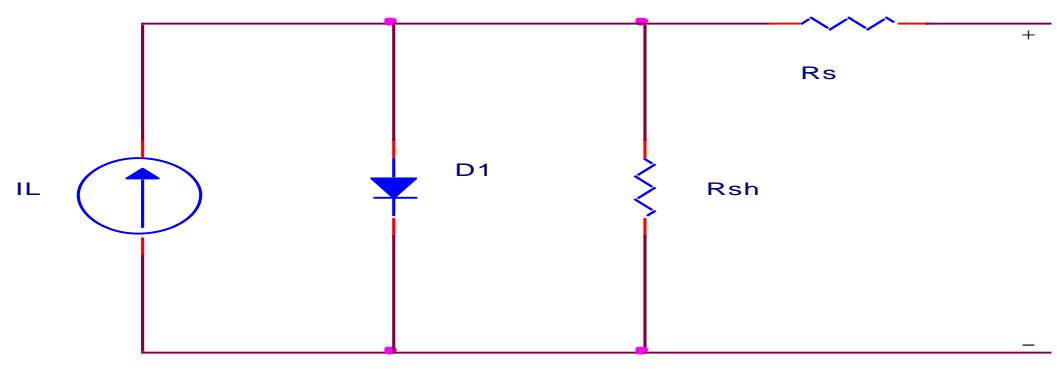

Figure 2. Circuit Diagram of Photovoltaic Cell

In exchange for the solar power to extract maximum power from the solar array, an MPPT (Maximum Power Point Tracking) is applied widely in modeling and application solar array as [9-10]. The voltage and current of PV model in equ (1) is substitute by $V_{M P P}$ and $I_{M P P}$ is given by:

$$
I_{M P P}=N_{P}\left\{I_{p h}-I_{0}\left\{\exp \left(\frac{q_{V_{M P P}}}{n N_{S} K T}\right)\right\}\right\}
$$

\subsubsection{MPPT}

The maximum power point tracking has generated high power from photovoltaic model. The parameter of photovoltaic energy generation such as voltage, power and current has extracted from PV. The incremental conductance has high tracking ability of power from the supply [11-12]. The following equation is described by left side maximum power increment and right side maximum power decrement as given by Figure 3 shows the flowchart of incremental conductance algorithm. The below following conditions are considered to track or extract maximum power using proposed MPPT Topology.

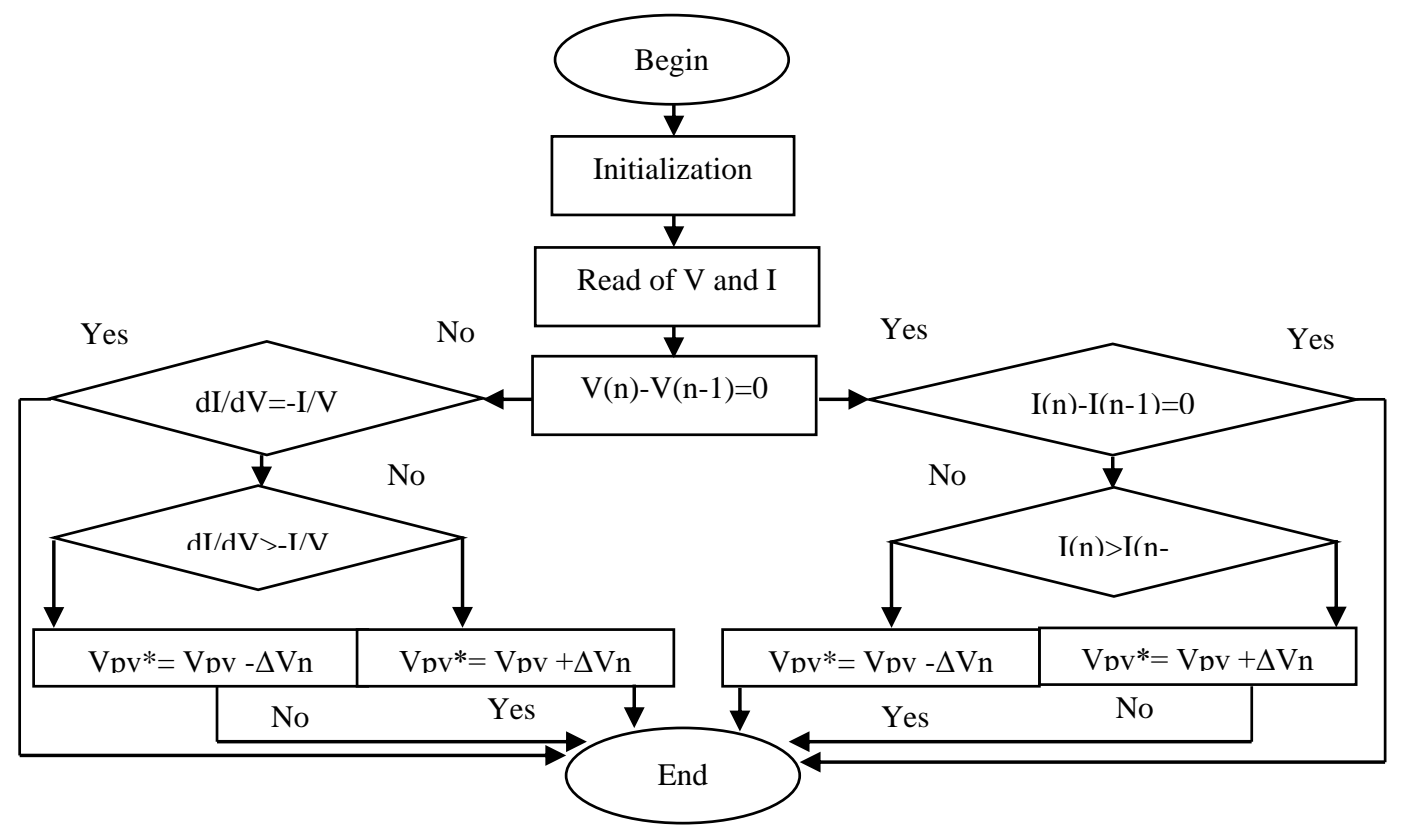

Figure 3. Flow Chart of Incremental Conductance Algorithm 


$$
\begin{aligned}
& d P / d V=0 \text { at MPP } \\
& d P / d V>0 \text { at right side of MPP } \\
& d P / d V<0 \text { at left side of MPP } \\
& d P / d V=d(V I) / d(V)=I+V I * d I / d V \\
& d I / d V=I / V \text { at MPP and } d V_{n}=0 \\
& d I / d V>-I / V \text { left of MPP } d V_{n}=+\delta \\
& d I / d V<-I / V \text { left of MPP } d V_{n}=-\delta
\end{aligned}
$$

\subsection{Wind Energy Generation}

In wind energy generation has utilized the turbine and generator for producing the power and utilize into power converter. The kinetic energy converts to mechanical energy using wind turbine. The electrical energy is generated by using generator for supplying mechanical energy. In wind turbine has revolving propeller-like blades around a rotor. The shaft of the wind turbines moves and produces electricity [13-14]. The maximum power from the wind turbine based on permanent magnet synchronous generator for various applications. The wind power depended on the speed, air density and swept the area.

$$
P=\frac{1}{2} \rho A V^{3}
$$

The amount of energy in the wind varying with the cube of wind speed and high-density air will generate more power. The area of the wind rotor rotate has generated high power of the turbine from the wind [7-8]. The swept area depends on the rotor radius, increase in blade length. The torque of wind turbine is given as:

$$
T=\frac{P}{\text { Rotorspeed }}
$$

The wind model is used for generating power from the permanent magnet synchronous generator, and turbine model has merits such as high efficiency and high power.

\section{MODIFIED CURRENT FED SWITCHED INVERTER}

The modified current fed switched inverter circuit is shown in Figure 4. The three-phase inverter utilizes the sinusoidal pulse width modulation for converting dc to alternating current. This inverter can generate high gain with the minimum passive element [15-20]. The PI-based incremental conductance has used to supply continuous power. The current fed device has two switches, three diodes, two capacitors and one inductor are connected to the supply and inverter circuit.

The current fed inverter methodology has two switches Sa and Sb has work simultaneously and generate the high voltage. The inverter operates under both shoot through and non shoot through the state. In the shoot, through the switch, Sa and Sb are on, and the inductor L1 is charging from supply and C1 [21-22]. In non-shoot through the state, the switch is turned off, and diode D1 and D2 are forward biased. The inductor charges the capacitor and power are fed into the inverter circuit. The current ripple across the inductor and voltage ripple across the capacitor is given as:

$$
\Delta I_{L 1}=\frac{V_{d c}+V_{C 2}}{L 1} D T_{s}
$$




$$
\Delta V_{C 2}=\frac{I_{L 1}}{C 2} D T_{S}
$$

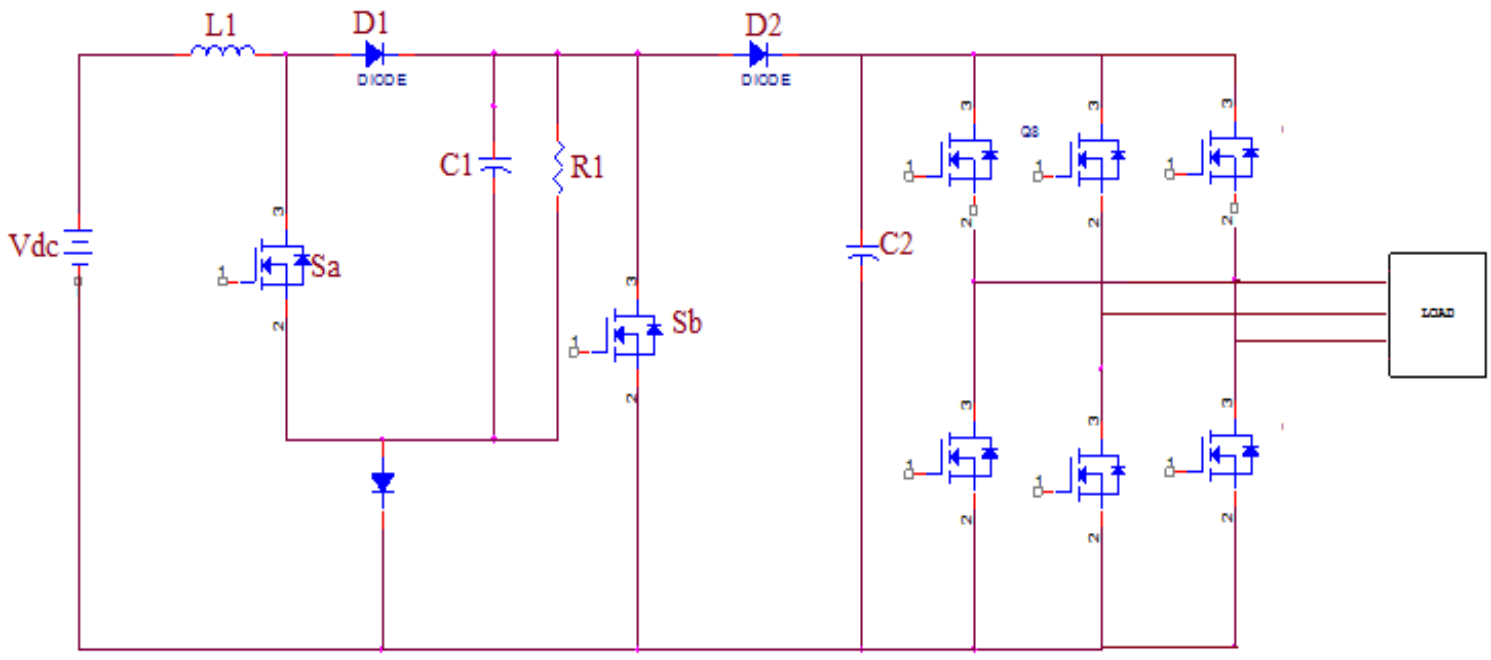

Figure 4. Circuit Diagram of Modified Current Fed Switched inverter

\section{CONTROL STRATEGY OF INVERTER CIRCUIT}

The PI-based MPPT control method has fed into the switch Sa and Sb. The photovoltaic output is fed into the controller circuit and generates the pulse of the converter side. The sinusoidal pulse width modulation is used in the inverter circuit. The sinusoidal waveform is compared to the triangular waveform for producing the pulse of the three-phase inverter. The pulse width modulation is employed for the control of switches. The inverter switching pulse is generated by comparing the sine and carrier signal. The sine wave is less than or equal to the carrier the pulse is generated and applied to S1 and inverting output is fed to the switch S4. The sinusoidal pulse generation circuit is shown in Figure 5.

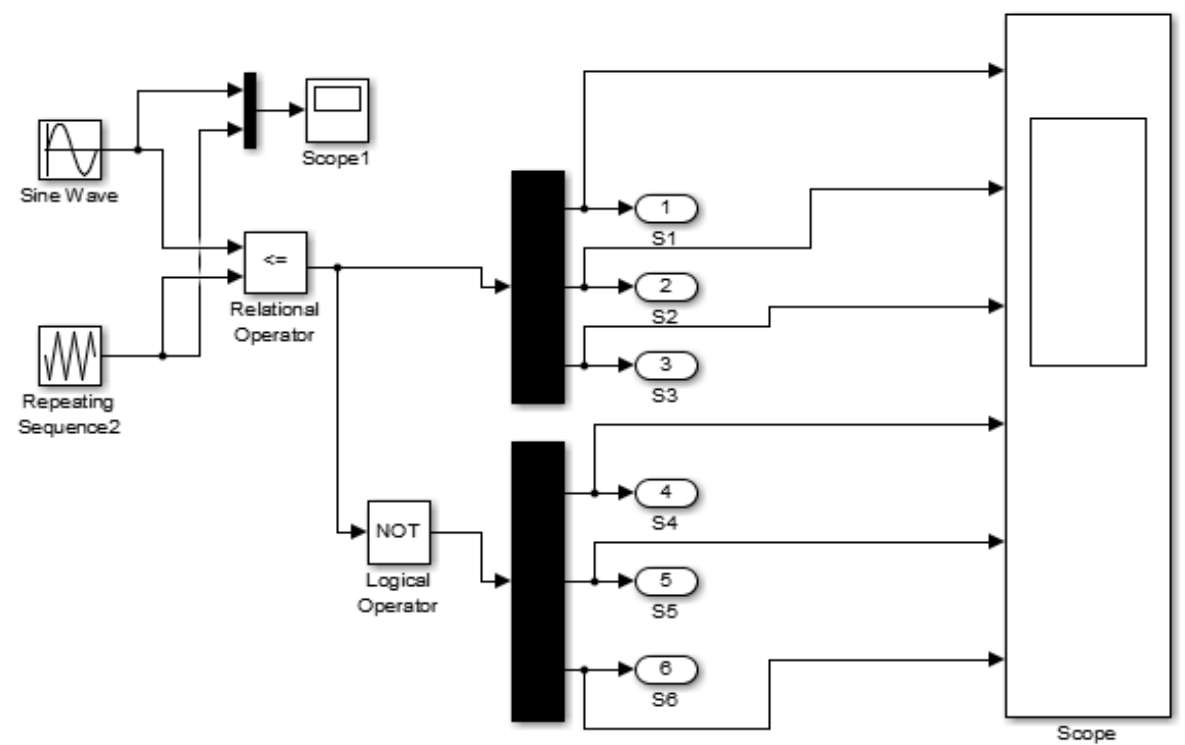

Figure 5. Circuit Diagram of Sinusoidal Pulse Width Modulation 


\section{RESULT ANALYSIS}

The proposed hybrid renewable energy based on current fed switched inverter configuration is implemented, and results are verified in MATLAB/SIMULINK. The overall Simulink proposed circuit diagram is shown in Figure 6. The photovoltaic and wind is connected in cascaded and generate voltage and fed into the current source inverter circuit. The PV output voltage waveform is shown in Figure 7. The PV output current waveform is shown in Figure 8.

The PI and incremental conductance based pulse generation is given to the inverter circuit. The dc link voltage of inverter circuit is shown in Figure 8. The output voltage waveform is shown in Figure 9. The output current waveform is shown in Figure 10. The harmonic distortion across output current of an inverter is 0.81 . The current fed switched inverter has generated the $118 \mathrm{~V}$ dc output from the $12 \mathrm{~V}$ supply and attained unity power factor at the inverter output. The resistive load is used in current fed switched inverter. The harmonic distortion waveform is shown in Figure 11.

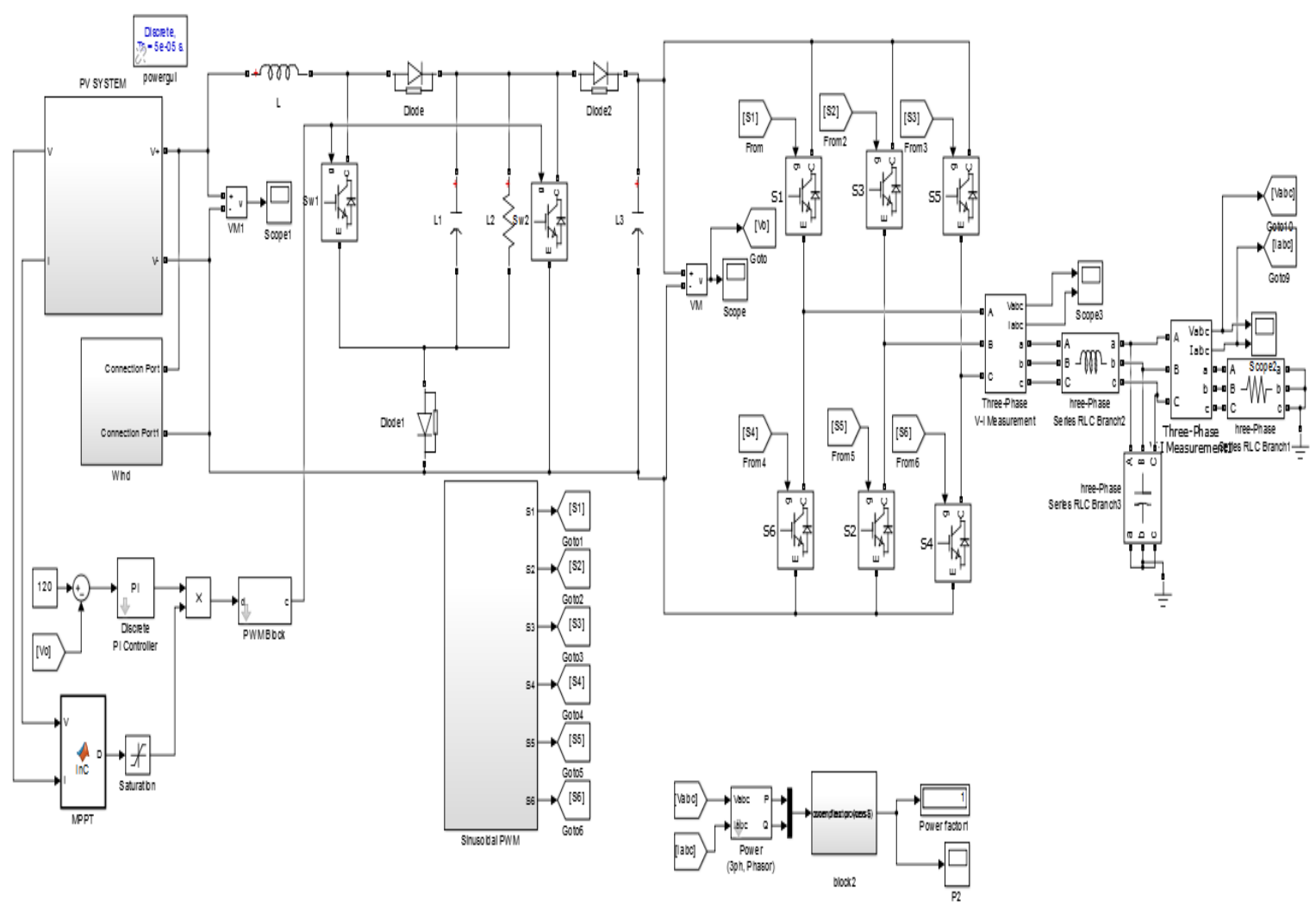

Figure 6. Overall Simulation circuit of Current fed Switched Inverter

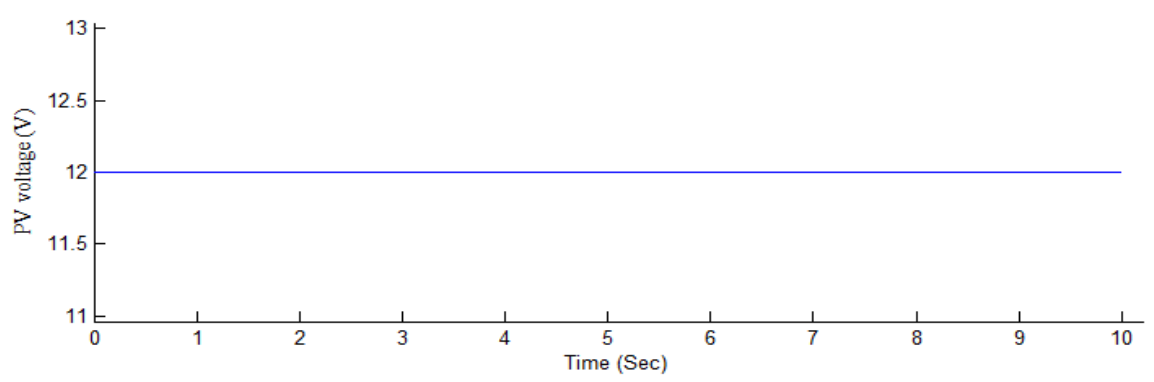

Figure 7. PV Voltage waveform 


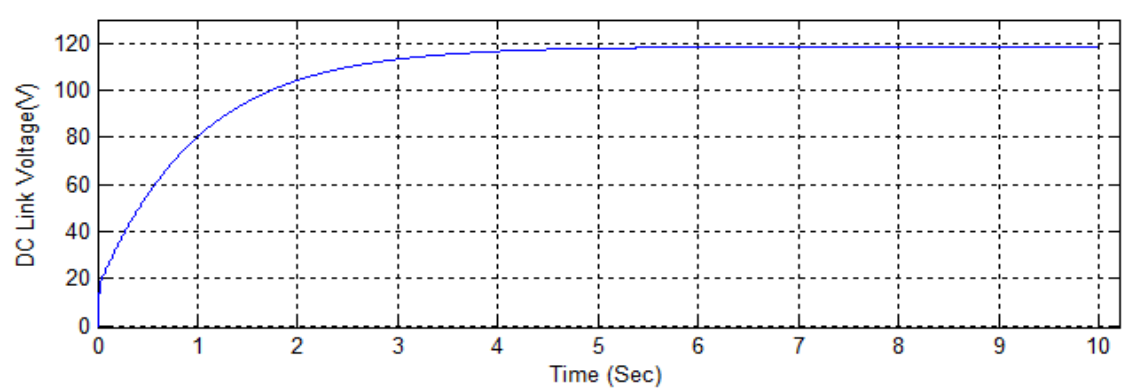

Figure 8. DC Link voltage

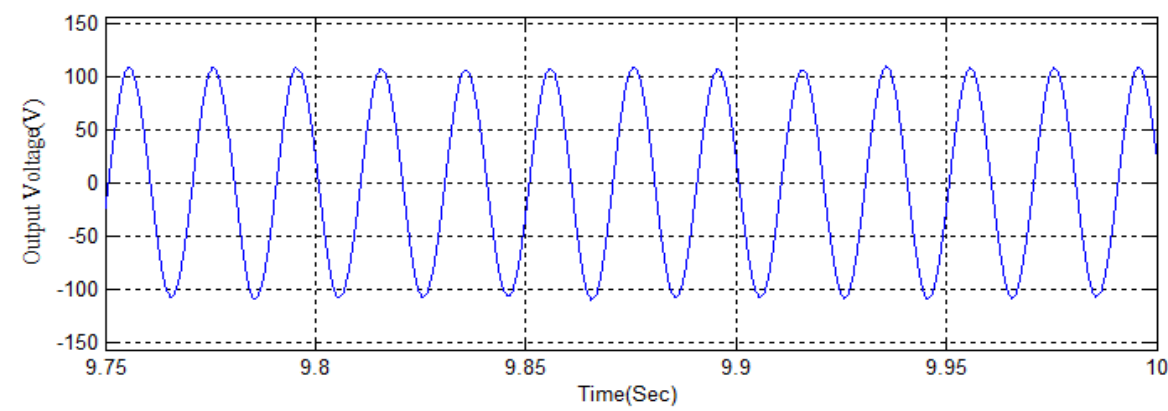

Figure 9. Output Voltage Waveform of the Modified Current Fed Switched inverter

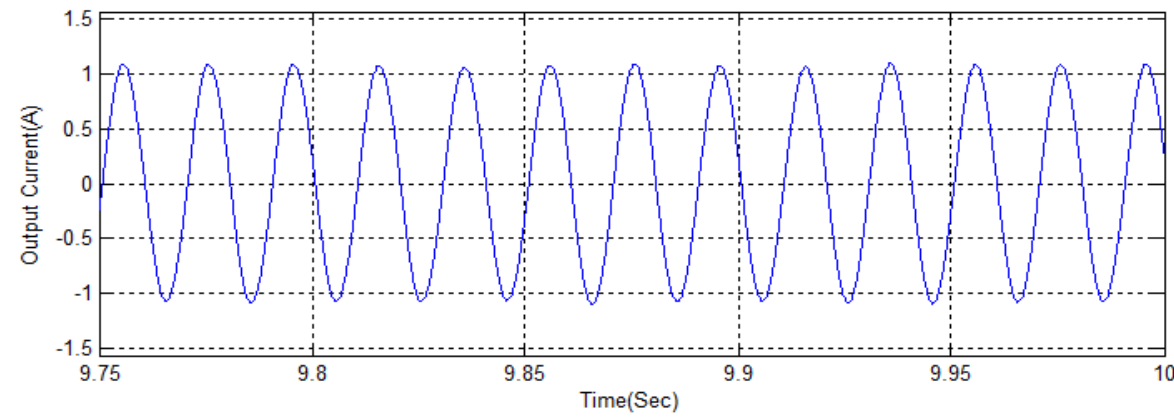

Figure 10. Output Current Waveform of Modified Current Fed Switched Inverter

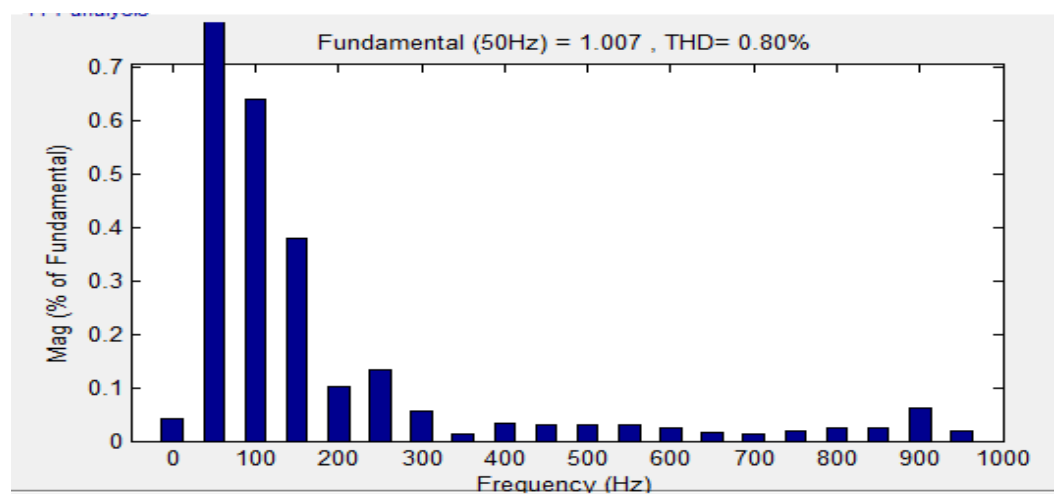

Figure 11. Total Harmonic Distortion 


\section{CONCLUSION}

The hybridizing solar and wind energy sources provide a realistic form of maximum power generation. A maximum Power Point Tracking (MPPT) algorithm acts a vital role in any renewable resource. However, centralized MPPT and distributed MPPT are two kinds of important MPPT strategies. Generally, the current source inverter offers higher reliability, versatile and higher efficiency compared to voltage source inverter. This paper proposes the modified Current Fed Switched Inverter (MCFSI) which combines the characteristics of Z-Source Inverter (ZSI) and reduces the passive elements in Switched Boost Inverter (SBI). The proposed inverter is based on current fed dc/dc topology and uses less L-C filter pair compared to ZSI. In order to reduce the harmonic, improve voltage gain, and improve the power factor and transformer less, threephase inverter methodology is implemented. Even though the passive components count increases, the voltage gain of the proposed paper is 9.8 and it has increased $46 \%$ than the conventional method.

\section{REFERENCES}

[1] Gambhir, et al., "A modified PWM scheme to reduce switching stress in a current-fed switched inverter," Industry Applications Society Annual Meeting, IEEE, pp. 1-7, 2017.

[2] Nag, et al., "Current-fed switched inverter," IEEE Transactions on Industrial Electronics, vol.61, no. 9, pp.46804690, 2014.

[3] Namadmalan and Alireza, "Bidirectional current-fed resonant inverter for contactless energy transfer systems," IEEE Transactions on Industrial Electronics, vol.61, no. 1, pp. 238-245, 2015.

[4] K. Sree, et al., "Soft-switching non-isolated current-fed inverter for PV/fuel cell applications," IEEE Transactions on Industry Applications, vol.52, no. 1, pp. 351-359, 2016.

[5] Lei, et al., "Novel loss and harmonic minimized vector modulation for a current-fed quasi-Z-source inverter in HEV motor drive application," IEEE Transactions on Power Electronics, vol.29, no. 3, pp.1344-1357, 2014.

[6] V. Vasudevan and K. Balaji, "Performance of Cuk-KY Converter Fed Multilevel Inverter for Hybrid Sources," Indonesian Journal of Electrical Engineering and Computer Science, vol. 10, no. 2, pp. 2018.

[7] Singaravel, et al., "MPPT with single DC-DC converter and inverter for grid-connected hybrid wind-driven PMSGPV system," IEEE Transactions on Industrial Electronics, vol.62, no. 8, pp.4849-4857, 2015.

[8] R. Balamurugan and R. Nithya, "FC/PV Fed SAF with Fuzzy Logic Control for Power Quality Enhancement," International Journal of Power Electronics and Drive Systems, vol. 5, no. 4 pp. 470-476, 2015.

[9] O.M. Benaissa, S. Hadjeri, and S. A. Zidi. "Modelling and Simulation of Grid Connected PV Generation System Using Matlab/Simulink." International Journal of Power Electronics and Drive Systems (IJPEDS) 8, no. 1 (2017): 392-401.

[10] Y. Tan, et al., "A model of PV generation suitable for stability analysis," IEEE Trans. Energy Converters, vol. 19, no. 4, pp. 748-755, Dec 2004.

[11] Y.C. Kuo and T.J. Liang, "Novel Maximum-Power-Point-Tracking Controller for Photovoltaic Energy Conversion System," IEEE Transactions on Industrial Electronics, vol. 48, no. 3, pp. 94- 601,2001.

[12] E. Zakzouk, et al., "Improved performance low-cost incremental conductance PV MPPT technique," IET Renewable Power Generation, vol.10, no. 4, pp.561-574, 2016.

[13] P. G. Arul, et al., "Control strategies for a hybrid renewable energy system: A review," Renewable and Sustainable Energy Reviews, vol.52, pp.597-608, 2015.

[14] Xuewei, et al., "Novel soft-switching snubberless naturally clamped current-fed full-bridge front-end-converter-based bidirectional inverter for renewable, micro grid, and UPS applications," IEEE Transactions on Industry Applications, vol.50, no. 6, pp.4132-4141, 2014.

[15] Gnanasambandam, et al., "Current-Fed Multilevel Converters: An Overview of Circuit Topologies, Modulation Techniques, and Applications," IEEE Transactions on Power Electronics, vol.32, no. 5, pp.3382-3401, 2017.

[16] A, Sundaram and G. P. Ramesh, "Sensor less Control of BLDC Motor using Fuzzy logic controller for Solar power Generation." International journal of MC square scientific research (IJMSR), vol.9, no. 2, 2017.

[17] G. P Ramesh and A. Jaffar Sadiq Ali, "Comparison of Boost and Interleaved Boost Converters for Wind Energy System," International Journal of Scientific \& Engineering Research, vol.5, no. 4, pp.81-86,2014.

[18] A. Jaffar Sadiq Ali, and G. P. Ramesh, "Comparison of PI and PID controlled wind generator fed $\Gamma-Z$ source based PMSM drives," Indian Journal of Science and Technology, vol.9, no.1, 2016.

[19] G.P. Ramesh and A. Sundaram, "MPPT Based Autonomous PV Module with Sensor Less Control of BLDC Motor for Maximum Solar Power Generations," International Journal of Control Theory and Applications, vol. 9, no. 6,pp 2911-2922,2017.

[20] A. Sundaram and G. P. Ramesh, "An Advance Solar Power Generation and Control of Brushless DC Motor Using Phase Current Infusion of Sensor Less Vector Control," International Journal of Computer Science and Application, 2016.

[21] C. K. Kishore and G. P. Ramesh., "Hybrid Energy System using Three Port Converter," International Journal of control theory and applications, (IJCTA), vol. 9, no. 5, pp.399-406, 2016.

[22] P. Magesh and G.P Ramesh, "Hybrid Renewable Energy System using Ultra Sparse Matrix Converter," International Journal of Control Theory and Applications, Vol. 9, no.31, pp 347-351, 2017. 